\title{
Fast Fluorine-18 Labeling and Preclinical Evaluation of Novel Mucin1 and its Folate Hybrid Peptide conjugate for Targeting Breast Carcinoma.
}

ibrahim aljammaz ( $\sim$ jammaz@kfshrc.edu.sa )

B. Al-Otaibi

King Faisal Specialist Hospital and Research Center

Y. Al-Malki

King Faisal Specialist Hospital and Research Center
A. Abousekhrah
King Faisal Specialist Hospital and Research Center
S. M. Okarvi
King Faisal Specialist Hospital and Research Center

\section{Research article}

Keywords: 18F-fluorination, 18F-fluoromucin 1, 18F-fluorofolate, hybrid-peptide, Breast cancer

Posted Date: July 29th, 2020

DOI: https://doi.org/10.21203/rs.3.rs-47894/v1

License: (c) (i) This work is licensed under a Creative Commons Attribution 4.0 International License. Read Full License

Version of Record: A version of this preprint was published on March 18th, 2021. See the published version at https://doi.org/10.1186/s41181-021-00127-y. 


\section{Abstract}

Background: There is a need to develop new and more potent radiofluorinated peptide and their hybrid conjugates for multiple-receptors targeting properties that overexpress on many cancers.

Methods: We have synthesized MUC1-[ $\left.{ }^{18} \mathrm{~F}\right] \mathrm{SFB}$ and MUC1-FA- $\left[{ }^{18} \mathrm{~F}\right] \mathrm{SFB}$ hybrid conjugates using a convenient and onestep nucleophilic displacement reactions. In vitro cell binding and in vivo evaluation in animals were performed to determine the potential of these radiolabeled compounds.

Results: Radiochemical yields for MUC1-[ $\left.{ }^{18} \mathrm{~F}\right] \mathrm{SFB}$ and MUC1-FA- $\left[{ }^{18} \mathrm{~F}\right] \mathrm{SFB}$ conjugates were greater than $70 \%$ in less than 30 min synthesis time. Radiochemical purities were greater than $97 \%$ without HPLC purification, which makes these approaches amenable for automation. In vitro studies on MCF7 breast cancer cells showed that the significant amounts of the radiofluorinated conjugates were associated with cell fractions and held good affinity and specificity for MCF7 cells. In vivo characterization in Balb/c mice revealed rapid blood clearance with excretion predominantly by urinary as well as hepatobiliary systems for MUC1-[18F]SFB and MUC1-FA-[18F]SFB, respectively.

Biodistribution in SCID mice bearing MCF7 xenografts, demonstrated excellent tumor uptake (12\% ID/g) and favorable kinetics for MUC1-FA-[18 F]SFB over MUC1-[ $\left.{ }^{18} \mathrm{~F}\right] \mathrm{SFB}$. The tumor uptake was blocked by the excess coinjection of cold peptides suggesting the receptor-mediated process.

Conclusion: Initial PET/CT imaging of SCID mice with MCF7 xenografts, confirmed these observations. These results demonstrate that MUC1-FA- $\left[{ }^{18} \mathrm{~F}\right] \mathrm{SFB}$ may be a useful PET imaging probe for breast cancer detection and monitoring tumor response to the treatment.

\section{Introduction}

Many tumor-associated antigens (TAAs) have been discovered and identified in the last decade and have provided new hope for the treatment of patients with malignant disease [1, 2]. The human epithelial mucin encoded by the gene MUC1 is an example of a tumor-specific antigen that is highly restricted on normal tissues but it is overexpressed on almost all human cancers (breast, ovarian, pancreatic, colorectal, lung, prostate, gastric cancers) and in particular, by primary and metastatic breast cancers [3-5], thus making MUC1 a promising tumor-antigen with diagnostic as well as therapeutic potential in the management and treatment of cancer $[6,7]$. Because overexpression of MUC1 correlates with high metastatic potential and poor patient survival, the ability to target such tumors may be highly beneficial in clinical settings $[3,5,8]$. The measurement of circulating MUC1 levels in the serum, as determined by the CA15-3 assay (approved by the US Food and Drug Administration), has been used to monitor the clinical course of patients with breast cancer during treatment and to detect early disease recurrence; and the elevated levels of serum MUC1 are always linked with poor survival $[3,5]$. Important leads have suggested that MUC1 is a promising target for the development of vaccines and a number of MUC1 peptide based cancer vaccines are currently in clinical trials [3-5]. Development of small peptide-based agents for targeting MUC1 expressing tumors is more desirable because of their low immunogenic response and favorable biokinetics, together with high affinity and selectivity for target receptors. MUC1 is a breast cancer-associated transmembrane glycoprotein, of which the extracellular domain is formed by the repeating 20 -amino acid sequence N-PDTRPAPGSTAPPAHGVTSA-C [9-11]. The unique extracellular domain of MUC1 is defined by the presence of the amino acid sequence PDTRP, which is the minimal MUC1 core peptide sequence (shown in bold above) $[3,6,12-15]$. The same pentamer sequence is also recognized by several highly tumor-specific anti-mucin monoclonal antibodies [12, 16-19]. In addition, it has been suggested that the PDTRP core peptide sequence attains a structure closer to the native 
conformation and is believed to be immunodominant in humans $[5,15,16]$. Thus, it is anticipated that the high expression of MUC1 on breast cancer would allow target-specific imaging and therapy using synthetic MUC1-derived peptide. Peptide-based tumor receptor binding agents have attracted enormous attention as biological vehicles to deliver radioactivity to tumor cells for receptor-targeted imaging and radiotherapy. Several peptides are currently under investigation to determine their clinical potential as imaging and therapeutic agents for different cancers [2023]. Recently, the synthesis and in vitro and in vivo characterization of new ${ }^{99 m}$ Tc-labeled-MUC1-derived peptide was reported suggesting the potential of this radiotracer for the targeted imaging of MUC1-positive breast cancer [24, 25]. However, more studies are required to determine the full potential of this peptide as breast cancer imaging agent. On other hand, membrane-folic acid receptor is a glycosylphospstidylinositol protein that overexpressed in various epithelial cancers including breast cancer $[26,27]$. Meanwhile, this receptor is highly restricted in most normal tissues which make these tumors as excellent candidates for molecular targeting through the folate receptor system. Recent studies demonstrate that approximately $30 \%$ of breast cancers express folate receptor alpha (FRA) and suggest that as many as $70-80 \%$ of a late stage metastatic triple negative breast cancer (TNBC) tumors express this receptor [28, 29]. Overexpression of both the MUC1 and FRA receptors on the breast cancer highlight the potential application of the radiolabeled MUC1-conjugated folate hybrid peptide as dual-receptor-targeting imaging probes for breast carcinoma imaging. We hypothesized that the unique radiofluorinated MUC1-conjugated folic acid (FA) hybrid peptide targeting both the MUC1 and folate receptors would be superior in breast cancer targeting to the radiofluorinated MUC1 monomeric peptide or folate targeting only the folate or folate receptors. This may represent novel multiple-acting properties to the management and treatment for breast cancer disease with unmet medical need. In this study, we have synthesized by solid-phase synthesis a novel MUC1-derived peptide based on PDTRP sequence and coupled to a negatively-charged glutamic acid (Glu) residue as a spacer to keep the chelating-site distant from the receptor-binding region and to increase the hydrophilicity of the ${ }^{18} \mathrm{~F}$-labeled peptide, which often resulted in faster renal excretion and improved target to background ratios. In addition, lysine (Lys) amino acid was terminally coupled with former sequence to facilitate conjugation with FA and radiolabeling with fluorine-18 $\left({ }^{18} \mathrm{~F}\right)$. Finally, the Lys (GAMMA) amino group was coupled to the activated (GAMMA) FA residue to yield MUC1-FA hybrid peptide. Owing to the favorable nuclear and chemical characteristics of ${ }^{18} \mathrm{~F}$ for PET diagnostic imaging applications including an appropriate physical half-life (109.7 min) and low positron $\left(\beta^{+}\right)$energy (0.64 MeV) [30], we here present the radiolabeling with ${ }^{18} \mathrm{~F}$ and in vitro and in vivo evaluation of new MUC1 and its FA hybrid peptides for the diagnosis of breast cancer using PET imaging.

\section{Experimental}

The chemicals used were all analytical reagent grades and used without further purification unless stated. Acetonitrile (ACN) and dimethylformamide (DMF) were kept over molecular sieves. High Pressure Liquid Chromatography (HPLC) analysis was carried out on Econosil C-18 reversed phase columns (semipreparative, $250 \mathrm{~mm} \times 10 \mathrm{~mm}$ or analytical, $250 \mathrm{~mm} \times 4.6 \mathrm{~mm}$ ). The solvent system used for the semipreparative was non-linear gradient (eluant $\mathrm{A}, \mathrm{H}_{2} \mathrm{O}$ with $0.1 \%$ trifluoroacetic acid (TFA); eluant $\mathrm{B}, \mathrm{ACN} / \mathrm{H}_{2} \mathrm{O}, 3 / 1 \mathrm{v} / \mathrm{v}$ with $0.1 \%$ TFA; gradient, 0 to $90 \%$ B, 90 to $90 \%$ B and 90 to $10 \%$ B over 10 min each at flow rate of $1.5 \mathrm{~mL} / \mathrm{min}$ ) and for the analytical was (eluant A, ACN with $0.1 \%$ TFA; eluant $B, \mathrm{H}_{2} \mathrm{O}$ with $0.1 \%$ TFA; gradient, 0 to $50 \% \mathrm{~B}$, over $0-15$ min and 50 to $0 \%$ B over $15-$ $20 \mathrm{~min}$ at flow rate of $1.5 \mathrm{~mL} / \mathrm{min}$ ). A Jasco chromatographic system equipped with a variable wavelength ultraviolet monitor and in tandem with a Canberra flow through radioactivity detector was used. Ultraviolet absorption was monitored at $220 \mathrm{~nm}$. Chromatograms were acquired and analyzed using BORWIN software. Mass spectroscopy was run on Quattra electrospray mass spectrometer (ES-MS). 


\subsection{MUC1and MUC1-FA hybrid peptide conjugates}

The MUC1 peptide analog was prepared utilizing the method reported previously [31]. Briefly, by solid-phase peptide synthesis (on a CS Bio peptide synthesizer, CA, USA) following standard Fmoc (9-fluorenylmethoxycarbonyl) chemistry, using Rink amide methylbenzhydrylamine (MBHA) resin on a $0.2 \mathrm{mmol}$ scale. After incorporating all the desired amino acids, the N-terminal Fmoc-protecting group was removed and the peptide was cleaved from the resin followed by the removal the other side-chain protecting groups using mixture of $\mathrm{TFA} / \mathrm{H}_{2} \mathrm{O} /$ dithiothreitol (DTT) 95:2.5:2.5 for $2 \mathrm{~h}$ at room temperature. The resin was removed by filtration, and the crude peptides obtained by precipitation with cold diethyl ether (ether) followed by HPLC purification. For the synthesis of MUC1-FA hybrid peptide, the free epsilon $(\mathbb{\nabla})$ amino group at terminal Lys residue on MUC1 peptide was coupled with FA via the activated gamma ( $\mathrm{Y}$ ) carboxyl moiety. The $\mathrm{N}$-succinimidyl folate ester (folate-NHS, $10 \mu \mathrm{mol}$ ) dissolved in dimethylsulfoxide (DMSO, $50 \mu \mathrm{L})$ and followed by the addition of each peptide $(10 \mu \mathrm{mol})$ and TEA $(10 \mu \mathrm{mol})$. Reaction mixture stirred while shielded from light for $30 \mathrm{~min}$ at $50^{\circ} \mathrm{C}$. The MUC1-FA hybrid peptide was precipitated by addition of ACN $(2 \mathrm{~mL})$, centrifuged and then washed several times with ACN before drying. The identity and purity of the MUC1 peptide analog was characterized by mass spectrometry and HPLC.

\subsection{Fluorinated MUC1- and MUC1-FA-SFB hybrid peptide reference conjugates}

The reference fluorinated MUC1 and MUC1-FA peptide conjugates were prepared separately by coupling the precursors 4-fluorobenzoic acid to the non-receptor binding region through an amide linkage utilizing the methods reported previously [31, 32] (Scheme 1). Briefly, MUC1 and MUC1-FA hybrid peptides (5 $\mu \mathrm{mol}$ each) were added to $N$ succinimidyl-4-fluorobenzoate (SFB, $8.5 \mu \mathrm{mol})$ in DMF $(100 \mu \mathrm{L})$ and enough amount of triethylamine $(\mathrm{TEA}, 2 \mu \mathrm{L})$ to attain a $\mathrm{pH}$ 9. The reaction mixtures were heated for $20 \mathrm{~min}$ at $90^{\circ} \mathrm{C}$. This was followed by dilution with $\mathrm{H}_{2} \mathrm{O}(1 \mathrm{~mL})$, loading onto Sep-Pak C-18 cartridge, washing with $\mathrm{H}_{2} \mathrm{O}(5 \mathrm{~mL})$ and the peptide conjugate eluted with ethanol (EtOH, $1 \mathrm{~mL}$ ). After solvents evaporation to dryness, white and slightly yellowish powders were separated and dried under vacuum to produce the reference MUC1-SFB or MUC1-FA-SFB hybrid peptide conjugates, respectively. The structures and purities of the fluorinated peptide analogs were characterized by mass spectrometry and HPLC.

\subsection{MUC1 and MUC1-FA 4-(N,N,N- trimethylammonium)benzoate.triflate hybrid peptide precursors}

The MUC1 and MUC1-FA hybrid peptide conjugates (3 mg, $3.5 \mu \mathrm{mol})$ were dissolved separately in DMF $(100 \mu \mathrm{L})$ followed by the addition of TEA $(1 \mu \mathrm{L}, 6 \mu \mathrm{mol})$. $N$-succinimidyl 4-(N,N,N-trimethylammonium)benzoate.triflate ( $1 \mathrm{mg}$, $3.6 \mu \mathrm{mol}$ ) was then added and mixtures stirred at $80^{\circ} \mathrm{C}$ for $15 \mathrm{~min}$ (Scheme 2). The MUC1- and MUC1-FA-triflate precursors were precipitated by addition of ACN $(1 \mathrm{~mL})$, centrifuged and then washed several times with ACN before drying under vacuum to yield white and slightly yellowish powders in $59 \%$ and $66 \%$, respectively.

\subsection{Radiosynthesis of MUC1-[18 F]- and MUC1-FA- $\left.{ }^{18} \mathrm{~F}\right] \mathrm{SFB}$ hybrid peptide conjugates}

Aqueous $\left[{ }^{18} \mathrm{~F}\right]$-fluoride was produced by the ${ }^{18} \mathrm{O}(\mathrm{p}, \mathrm{n}){ }^{18} \mathrm{~F}$ reaction. The fluoride activity $(2-8 \mathrm{mCi}, 74-296 \mathrm{MBq})$ was trapped in Kryptofix 2.2.2 (5 mg) and potassium carbonate $(1 \mathrm{mg})$ in $\mathrm{ACN} / \mathrm{H}_{2} \mathrm{O}$ solution $(950 \mu \mathrm{L} / 50 \mu \mathrm{L})$, dried by azeotropic distillation with aliquots of $\mathrm{ACN}$. The solid residue was resolubilized in DMF $(0.2 \mathrm{~mL})$ and reacted in two different sealed vials containing the precursor Mucin 4-(N,N,N-trimethylammonium)benzoate.triflate peptide (50 $\mu \mathrm{g}$, $50 \mathrm{nmol})$ and MUC1-FA 4-(N,N,N-trimethylammonium)benzoate.triflate hybrid peptide (50 $\mu \mathrm{g}, 35 \mathrm{nmol})$. The reaction 
mixtures were heated in capped $2 \mathrm{~mL}$ reaction-vials at $90^{\circ} \mathrm{C}$ for $5 \mathrm{~min}$, followed by the addition of $\mathrm{H}_{2} \mathrm{O}(1 \mathrm{~mL})$ then passed through Sep-Pak C18 cartridge and washed with $\mathrm{H}_{2} \mathrm{O}(5 \mathrm{~mL})$ to remove hydrophilic impurities $($ Scheme 3,4$)$. Sep-Pak C18 cartridge was then dried with steady stream of nitrogen, MUC1-[ $\left.{ }^{18} \mathrm{~F}\right] \mathrm{SFB}$ and MUC1-FA- $\left[{ }^{18} \mathrm{~F}\right] \mathrm{SFB}$ hybrid peptide conjugates were eluted with $\mathrm{EtOH}(1 \mathrm{~mL})$. EtOH solutions were dried and residues were then re-solubilized in saline ( $\mathrm{NaCl} 0.9 \%, 1 \mathrm{~mL}$ each) before passing through $0.22 \mu \mathrm{m}$ pore membrane filter for further studies.

\subsection{Partition Coefficient}

$100 \mu \mathrm{L}$ of MUC1-[18 F]SFB and MUC1-FA-[ $\left.{ }^{18} \mathrm{~F}\right]$ SFB hybrid peptide conjugates were added into test tubes containing $1 \mathrm{~mL}$ of each n-octanol and buffered $\mathrm{H}_{2} \mathrm{O}(\mathrm{pH}=7.3)$. The tubes were shaken for $1 \mathrm{~min}$. After partial separation of the phases by gravity, $0.7 \mathrm{~mL}$ of each phase was transferred to separate tubes and centrifuged at $5000 \mathrm{rpm}$ for $5 \mathrm{~min}$. Duplicate $0.2 \mathrm{~mL}$ aliquots of each phase was taken for radioactivity measurement and the partition coefficient was determined by the function: Partition coefficient $=\log _{10}$ (counts in n-octanol layer/counts in aqueous layer).

\subsection{Stability in Plasma}

For stability in plasma, the purified MUC1-[18 F]SFB and MUC1-FA-[18 F]SFB hybrid peptide conjugates $(100 \mu \mathrm{L}, 20 \mu \mathrm{Ci}$ each) were incubated with human plasma $(500 \mu \mathrm{L})$ in duplicate at $37^{\circ} \mathrm{C}$ for $2 \mathrm{~h}$. This was followed by precipitation using a mixture of ACN/EtOH (400 $\mu \mathrm{L}, 1: 1 \mathrm{v} / \mathrm{v})$ and centrifugation at $5000 \mathrm{rpm}$ for $5 \mathrm{~min}$. The supernatant layer was then analyzed by HPLC under the conditions described above.

\subsection{In Vitro Cell Binding}

The cell-binding activity of the MUC1-[18 F]SFB and MUC1-FA-[ $\left.{ }^{18} \mathrm{~F}\right] \mathrm{SFB}$ hybrid peptide conjugates were measured on human MCF7 breast cancer cell line (ATCC, Rockville, MD). MCF7 cell line was grown in RPMI-1640 culture media with $10 \%$ fetal bovine serum (FBS) in tissue culture flasks. $24 \mathrm{~h}$ prior conducting the cell-binding assay, media was replaced with RPMI-1640 without further addition of FBS. Confluent cultures were harvested by trypsinization, and 6 $\times 10^{6}$ cells were suspended in $1.8 \mathrm{~mL}$ of sterile saline for binding assay. Approximately 300,000 cells (in $0.3 \mathrm{~mL}$ of sterile saline) were incubated with various amounts of the purified MUC1-[ $\left.{ }^{18} \mathrm{~F}\right] \mathrm{SFB}$ and MUC1-FA-[ $\left.{ }^{18} \mathrm{~F}\right] \mathrm{SFB}$ hybrid peptide conjugates ranging from $0.3-18 \mathrm{nM}$ in duplicate for $60 \mathrm{~min}$ at room temperature. Incubation was terminated by dilution with cold saline $(0.3 \mathrm{~mL})$ and cells were pelleted by centrifugation. The cell-pellets were then washed with cold saline to remove unbound radioactivity and centrifuged to collect supernatants. Radioactivity in the cell-pellets (total bound) and washings (unbound) were measured in a y-well counter. Non-specific binding, was determined in the presence of approximately 100-fold excess of unlabeled MUC1 and MUC1-FA- hybrid peptide. Specific binding was calculated by subtracting the non-specific bound radioactivity from that of the total binding. The data were analyzed by a non-linear regression analysis program (Graph-Pad Software Inc., San Diego, CA, USA) using one-site binding equation. All binding data were corrected for non-specific binding and presented as the mean \pm S.D.

\subsection{In vivo Biodistribution}

Approval for the animal protocol used in this study was obtained from the Institutional Animal Care and Use Committee. Animal biodistribution experiments were performed according to the international regulations governing the safe and humane use of laboratory animals in research [33]. The biodistribution was performed in normal female $\mathrm{Balb} / \mathrm{c}$ mice (body mass $20-25 \mathrm{~g}$ ) to ascertain the in vivo distribution profile of the MUC1-[ $\left.{ }^{18} \mathrm{~F}\right] \mathrm{SFB}$ and MUC1-FA$\left[{ }^{18} \mathrm{~F}\right]$ SFB hybrid peptide conjugates. Mice were injected via the lateral tail vein with $100 \mu \mathrm{L}$ of the radiotracers formulated in saline. Each dose contained $20 \mu \mathrm{Ci}(740 \mathrm{kBq})$ of radioactivity. Animals were sacrificed at different time intervals and tissues of interest were dissected, weighed and assayed for radioactivity. The percentage of the injected 
dose per gram (\% ID/g) was then calculated by counting all tissues in a $\mathrm{y}$-well counter using a stored sample of the injection solution as a standard to estimate the total dose injected per mouse.

\subsection{In vivo tumor targeting}

Human MCF7 xenografts SCID female mouse models were used for in vivo tumor targeting experiments. For the implantation of tumor xenografts, approximately $3 \times 10^{6} \mathrm{MCF} 7$ cells in suspension of $100 \mu \mathrm{L}$ sterile saline were injected subcutaneous into the right thigh of each mouse. Tumors were allowed to grow for 4-6 weeks by which tumors had reached weights of $\sim 500 \mathrm{mg}$. Animals were injected with $20 \mu \mathrm{Ci}(740 \mathrm{kBq})$ of the radiotracers. For the blocking studies, each animal was intravenously injected with excess cold of MUC1 and MUC1-FA hybrid peptide ( $100 \mu \mathrm{g}) 30 \mathrm{~min}$ prior to the radiotracers injection. The animals ( $n=4$ per group) were sacrificed at 60 min post radiotracers injection (p.i.) and the \% ID/g for the tumor and major organs was calculated as described above.

\subsection{In vivo Nano PET/CT imaging}

PET/CT scans were performed using a preclinical NanoPET/CT scanner (Mediso, Hungary) on MCF7 tumor-bearing SCID female mice (8 weeks old). MUC1-[18 F]SFB and MUC1-FA- $\left[{ }^{18}\right.$ F]SFB hybrid peptide conjugates $(7.4 \mathrm{MBq} / 100 \mu \mathrm{L})$ were injected into each mouse through tail vein and placed in the Nano PET/CT scanner with continuous $\mathrm{O}_{2}$ and $2 \%$ isoflurane supply. 20 min post tail vein injection of the radiotracers, the mouse was imaged for $30 \mathrm{~min} P E T / C T$ acquisition time. Static scan was acquired at $60 \mathrm{~min}$ post- injection. CT scan was performed using the following parameters: $X$-ray voltage $=50 \mathrm{kVp}$, Exposure time $=300 \mathrm{~ms}$. A total projection of 288 projects over $360^{\circ}$ of rotation were acquired and reconstructed using a cosine filter. This was followed by a PET data acquisition with following parameters: 5-ns coincidence window and 400-600 keV energy window in 1-5 coincidence mode. Crystal efficiency correction was also applied, with a ring difference of 8 , and the images were reconstructed by a three-dimensional ordered-subsets; exception maximum algorithm (subsets, 4; iterations, 6). Pixel size was $0.3 \mathrm{~mm}$. The acquired data in these studies were analyzed by InterVeiw FUSION software developed by Mediso.

\subsection{Statistical analysis}

Data are expressed as mean \pm S.D. where appropriate. For data comparisons, a Student's $t$ test was performed of the mean values using Graph-Pad Software (Graph-Pad Software Inc., San Diego, CA, USA). A probability value of $\mathrm{P}<$ 0.05 was considered statistically significant.

\section{Results And Discussion 3.1 Organic chemistry}

The MUC1 peptide investigated was successfully prepared in good yields (30\%) by solid-phase synthesis according to standard Fmoc/HBTU methodology. After completion of solid-phase synthesis, free $\nabla$ amino group on lysine terminus of MUC1 peptide was coupled to activated $\gamma$-folate carboxylate to furnish MUC1-FA hybrid peptide in $85 \%$ yield. The purities of these peptides were found to be greater than $97 \%$ as characterized by analytical HPLC and the calculated molecular masses for MUC1 and MUC1-FA hybrid peptides were in agreement with the experimentally found ES-MS $[M+1]^{+}$values 841 and 1264, respectively. The synthesis of amide-linked reference MUC1-SFB and MUC-FA-SFB hybrid peptide conjugates entailed several sequence of reactions as illustrated in Scheme 1. All these conjugates were obtained as white and slightly yellowish powders, respectively, and the overall yields and chemical purities were greater than $80 \%$. The calculated molecular mass for the fluorinated MUC1-SFB and MUC1-FA-SFB hybrid peptide conjugates were 962.1 and 1378.5 and were in agreement with the found molecular ion ES-MS [M + 1] ${ }^{+}$ 
= 963 and 1379, respectively. The key precursors 4-N,N,N-trimethylammonium benzoate-MUC1 and MUC1-FA-triflate precursors were prepared by reacting $\mathrm{N}$-succinimidyl 4-N,N,N-trimethylammonium benzoate with MUC1 and MUC1-FA hybrid peptides to furnish both peptide triflate precursors in more than $70 \%$ yield and $>95 \%$ chemical purity (Scheme 2). The calculated molecular mass for MUC1 and MUC1-FA hybrid peptide triflate conjugates were 1003.9 and 1418.6 , respectively and were in agreement with the attained ES-MS $[M+1]^{+}=1004$ and 1419, respectively.

\subsection{Radiochemistry}

The synthetic approaches for preparation of MUC1-[18 F]SFB and MUC1-FA-[ $\left.{ }^{18} \mathrm{~F}\right] S F B$ hybrid peptide conjugates entailed only a one-step reaction (Scheme 3,4$)$. Both precursors were treated using catalyzed nucleophilic no-carrieradded radiofluoride produced by the ${ }^{18} \mathrm{O}(\mathrm{p}, \mathrm{n}){ }^{18} \mathrm{~F}$ nuclear reaction on ${ }^{18} \mathrm{O}$-enriched (98\%) water and Kryptofix 222 as nucleophilic catalyst in anhydrous DMF at $80^{\circ} \mathrm{C}$ for $5 \mathrm{~min}$. The radiofluorinated peptides were purified by $\mathrm{C}-18 \mathrm{Sep}-$ Pak column and the overall radiochemical yields for MUC1-[18 $\mathrm{F}]$ SFB and MUC1-FA- $\left[{ }^{18} \mathrm{~F}\right] \mathrm{SFB}$ hybrid peptide conjugates were greater than $70 \%$ (based on starting $\left[{ }^{18} \mathrm{~F}\right]$-fluoride), in less than 30 min total synthesis time. As shown in Fig. 1, radiochemical purities of MUC1-[18 F]SFB and MUC1-FA-[ $\left.{ }^{18} \mathrm{~F}\right] \mathrm{SFB}$ hybrid peptide conjugates were always greater than $98 \%$, as determined by HPLC with retention times of 11.4 and 15.4 min, respectively. This synthetic approach holds considerable promise as a rapid and efficient method amenable for automation for the radiofluorination of peptides, with high radiochemical yield and short synthesis time. In addition, the calculated partition coefficient for MUC1-[18 F]SFB and MUC1-FA- $\left[{ }^{18} \mathrm{~F}\right]$ SFB hybrid peptide conjugates were found $-2.030 \pm 0.09$ and $-1.14 \pm 0.08$, respectively, representing a low lipophilic characteristic for both conjugates. Moreover, the specific activities for MUC1-[18 F]SFB and MUC1-FA-[ $\left.{ }^{18} \mathrm{~F}\right]$ SFB hybrid peptide conjugates were always greater than $1000 \mathrm{mCi} /$ $\mu \mathrm{mol}$. Hence, these radiofluorinated-peptide conjugates could be suitable for biochemical studies, such as radioligand binding assays.

\subsection{Stability in Plasma}

The proteolytic degradation of the MUC1-[ $\left.{ }^{18} \mathrm{~F}\right] \mathrm{SFB}$ and MUC1-FA- $\left[{ }^{18} \mathrm{~F}\right] \mathrm{SFB}$ hybrid peptide conjugates were determined in human plasma in vitro. HPLC analysis of the plasma revealed that both radioconjugates remained sufficiently stable (>99\%) during incubation at $37^{\circ} \mathrm{C}$ for at least $4 \mathrm{~h}$, demonstrating a high in vitro stability of these radioconjugates.

\subsection{In Vitro Cell Binding}

The binding affinities $\left(K_{\mathrm{d}}\right)$ for MUC1-[18 F]SFB and MUC1-FA- $\left[{ }^{18} \mathrm{~F}\right]$ SFB hybrid peptide conjugates were evaluated by using MCF7 breast cancer cell line. The $K_{d}$ values of these bioconjugates were determined by saturation assays (Fig. 2). The results demonstrate that the conjugate MUC1-FA- $\left[{ }^{18} \mathrm{~F}\right] S F B$ hybrid peptide has higher binding affinities to MCF7 breast cancer cell line than MUC1-[18 F]SFB conjugate (4.06 \pm 0.15 and $19.31 \pm 4.23 \mathrm{nM})$. This result indicates

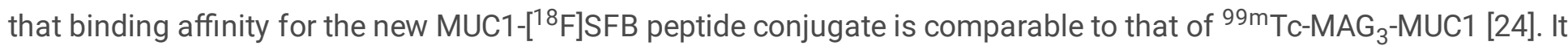
is generally expected that hybrid molecules, capable of targeting dual receptor system, may improve tumor targeting efficacy of the compound by increasing the accumulation of radioactivity in the tumors. This is because more tumor cells would be targeted with hybrid radioligand than would be possible with only a single radioligand. The same trend was true for MUC1-FA-[ $\left.{ }^{18} \mathrm{~F}\right]$ SFB hybrid peptide conjugate, where the affinity increased by five folds after the conjugation of MUC1 to folic acid. Additional studies are required to get better insight of this binding variation.

\subsection{In vivo biodistribution and tumor uptake}


The biodistribution data in normal female Balb/c mice for MUC1-[18 $\mathrm{F}] \mathrm{SFB}$ and MUC1-FA- $\left[{ }^{18} \mathrm{~F}\right] \mathrm{SFB}$ hybrid peptide conjugates at 10,60 and 120 min p.i. are shown in Tables 1 and 2. The results of biodistribution for MUC1-[ $\left.{ }^{18} \mathrm{~F}\right] \mathrm{SFB}$ peptide conjugate generally demonstrate fast and efficient clearance from the blood and most of the organs and tissues. Peptide conjugate MUC1-[18 F]SFB, displayed moderate radioactivity uptake in the kidneys suggesting that the major route of elimination was the urinary system. Whereas, MUC1-FA- $\left.{ }^{18} \mathrm{~F}\right] \mathrm{SFB}$ hybrid peptide conjugate revealed fast clearance from the blood and slightly higher radioactivity accumulations in most of the organs. However, significant radioactivity accumulation in the kidneys and intestines was observed suggesting that the route of elimination was the both urinary and hepatobiliary systems. The higher radioactivity uptake in kidneys for MUC1-FA$\left[{ }^{18} \mathrm{~F}\right] \mathrm{SFB}$ hybrid peptide in comparison with MUC1-[18 $\left.\mathrm{F}\right] \mathrm{SFB}$ peptide is likely a result of the presence of folate receptor in the proximal tubules. These results are in agreement with the partition coefficient measurements performed previously. In addition, the lower bone activity for these conjugates can be due to the high stability of the carbonfluorine bond.

Table 1

Biodistribution of the MUC1-[18 F]SFB peptide conjugate in normal mice.

\begin{tabular}{|llllllllll|}
\hline min & Blood & Liver & Lung & Kidney & Intestine & Heart & Muscle & Bone & Spleen \\
\hline 10 & $9.77 \pm$ & $12.1 \pm$ & $4.52 \pm$ & $11.42 \pm$ & $3.48 \pm$ & $4.77 \pm$ & $1.29 \pm$ & $1.34 \pm$ & $2.77 \pm$ \\
& 1.02 & 0.39 & 0.55 & 2.41 & 1.01 & 0.69 & 0.09 & 0.16 & 0.25 \\
60 & $2.80 \pm$ & $2.88 \pm$ & $1.34 \pm$ & $3.43 \pm 0.45$ & $1.94 \pm$ & $1.77 \pm$ & $1.13 \pm$ & $1.31 \pm$ & $1.06 \pm$ \\
& 0.50 & 0.66 & 0.16 & & 0.23 & 0.24 & 00.46 & 0.28 & 0.19 \\
120 & $1.34 \pm$ & $1.59 \pm$ & $0.66 \pm$ & $1.09 \pm$ & $0.65 \pm$ & $0.44 \pm$ & $0.69 \pm 0.17$ & $0.75 \pm$ & $0.24 \pm$ \\
& 0.24 & 0.57 & 0.12 & 0.45 & 0.16 & 0.23 & & 0.27 & 0.09
\end{tabular}

The values are average of $\%$ injected dose/gram \pm SD for $n=4$.

Table 2

Biodistribution of the MUC1-FA- $\left[{ }^{18} \mathrm{~F}\right] \mathrm{SFB}$ hybrid peptide conjugate in normal mice.

\begin{tabular}{|llllllllll|}
\hline min & Blood & Liver & Lung & Kidney & Intestine & Heart & Muscle & Bone & Spleen \\
\hline 10 & $3.63 \pm$ & $7.17 \pm$ & $7.84 \pm$ & $11.09 \pm$ & $4.35 \pm$ & $3.57 \pm$ & $2.05 \pm$ & $0.20 \pm$ & $2.72 \pm$ \\
& 0.24 & 1.75 & 1.74 & & 0.91 & 0.19 & 0.45 & 0.09 & 0.65 \\
\hline 60 & $0.97 \pm$ & $2.61 \pm$ & $4.19 \pm$ & $5.36 \pm 0.10$ & $4.11 \pm$ & $1.17 \pm$ & $0.58 \pm$ & $0.02 \pm$ & $2.99 \pm$ \\
& 0.14 & 0.69 & 0.35 & & 0.34 & 0.24 & 00.24 & 0.01 & 0.89 \\
120 & $0.39 \pm$ & $1.00 \pm$ & $1.15 \pm$ & $2.39 \pm$ & $3.29 \pm$ & $0.41 \pm$ & $0.15 \pm 0.04$ & $0.01 \pm 0.0$ & $1.96 \pm$ \\
& 0.14 & 0.28 & 0.51 & 0.42 & 0.55 & 0.12 & & & 0.82 \\
\hline
\end{tabular}

The values are average of $\%$ injected dose/gram \pm SD for $n=4$.

In female SCID mice bearing human MCF7 cell line xenografts, MUC1-[18$F] S F B$ peptide conjugate displayed a rapid clearance from the blood, with $0.35 \pm 0.11 \% \mathrm{ID} / \mathrm{g}$ of radioactivity remained in the blood after $60 \mathrm{~min}$ p.i. (Table 3). In contrast with normal mice studies, a moderate uptake of MUC1-[18 F]SFB peptide conjugate was also found in most of organs and tissues. The exact reason for the low uptake is unclear, but we assume that this behavior may be 
attributed to the nature of mouse strain. Good tumor uptake was observed for MUC1-[18 F]SFB peptide conjugate $(2.936 \pm 0.12 \% \mathrm{ID} / \mathrm{g})$ at $60 \mathrm{~min}$ p.i. and tumor-to-blood and tumor-to-muscle ratios obtained were 8.37 and 13.32 , respectively. A fairly high uptake by the tumors combined with good tumor to background uptake ratios advocating the possible potential of this tumor-specific antigen peptide for targeting human breast cancer. In a blocking study where $100 \mu \mathrm{g}$ of MUC1 peptide was administered $30 \mathrm{~min}$ before the injection of MUC1-[18 F]-SFB peptide conjugate reduced the uptake in the tumors by approximately $45 \%$ ( $1.61 \pm 0.22 \% \mathrm{ID} / \mathrm{g}$ blocked vs. $2.93 \pm 0.12 \% \mathrm{ID} / \mathrm{g}$ unblocked, $P=0.01)$, highlighting the specificity of the MUC1-[18F]SFB peptide for respective MUC1-positive breast cancer cell line. No marked influence of the blocking dose was observed in other major organs and tissues. It is worth mentioning that the biodistribution and tumor uptake profiles of MUC1-[ $\left.{ }^{18} \mathrm{~F}\right] \mathrm{SFB}$ peptide conjugate is superior to the

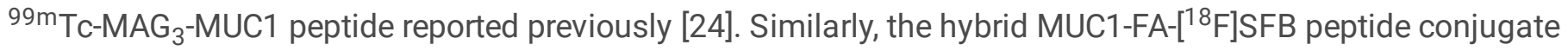
displayed fast clearance from the blood and an excellent tumor uptake of $12.03 \pm 0.57 \% \mathrm{ID} / \mathrm{g}$ at $1 \mathrm{~h}$ p.i. The uptake value in the tumor was always higher than the radioactivity in other organs and much higher than uptake values for the blood and muscle and was 17.9 and 19.8, respectively. The high uptake by the tumors combined with good tumor to background uptake ratios indicating the potential of this peptide for targeting human breast cancer. The high tumor uptake was dramatically decreased $(12.03 \pm 0.57 \%$ vs. $1.37 \pm 0.22 \% \mathrm{ID} / \mathrm{g}, P=0.02)$ in the presence of a blocking dose of the full sequence MUC1-FA. This indicates the specificity of the MUC1-FA- $\left[{ }^{18} \mathrm{~F}\right] S \mathrm{FB}$ hybrid peptide for MUC1-positive breast cancer cell line. Marked influence of the blocking dose was observed also in kidneys which is a result of the masking of folate receptor in the proximal tubules. The rapid clearance from the blood and the excretion mainly by renal pathway for MUC1-[18 F]SFB peptide and by renal as well as hepatobiliary pathways for MUC1-FA$\left[{ }^{18} \mathrm{~F}\right]$ SFB hybrid peptide is attributed to the hydrophilic characteristic of former in comparison with the latter as demonstrated in the partition coefficient measurement. The amounts of radioactivity of all the conjugates excreted into the urine at the time of sacrifice (60 min p.i.) were collected and examined by HPLC to determine the in vivo stability MUC1-[ ${ }^{18}$ F]SFB and MUC1-FA- $\left[{ }^{18} \mathrm{~F}\right]$ SFB hybrid peptide conjugates. Radio-HPLC analysis of the urine samples showed that significant amount of the radioactivity (>95\%) was still associated with the radioconjugates. These finding demonstrate that these radioflorinated conjugates are not prone to rapid in vivo degradation and correlate well with the findings of high metabolic stability in human plasma in vitro. 
Table 3

Biodistribution of the MUC1-[18 F]SFB and MUC1-FA- $\left[{ }^{18} \mathrm{~F}\right] \mathrm{SFB}$ hybrid peptide conjugates in tumor-bearing SCID mice.

\begin{tabular}{|c|c|c|c|c|}
\hline & \multirow{3}{*}{$\begin{array}{l}\text { MUC1-[18 F]SFB } \\
60 \mathrm{~min}\end{array}$} & \multicolumn{3}{|c|}{ MUC1-FA-[ $\left.{ }^{18} F\right] S F B$} \\
\hline & & $60 \mathrm{~min}$ & $60 \mathrm{~min}$ & $60 \mathrm{~min}$ \\
\hline & & blocked & & blocked \\
\hline Blood & $0.35 \pm 0.11$ & $0.39 \pm 0.15$ & $0.67 \pm 0.07$ & $0.52 \pm 0.05$ \\
\hline Liver & $0.85 \pm 0.07$ & $0.55 \pm 0.17$ & $3.20 \pm 0.36$ & $2.14 \pm 0.13$ \\
\hline Lung & $1.39 \pm 0.42$ & $0.99 \pm 0.22$ & $2.96 \pm 0.40$ & $2.05 \pm 0.49$ \\
\hline Kidney & $1.28 \pm 0.03$ & $1.20 \pm 0.23$ & $5.14 \pm 0.53$ & $1.86 \pm 0.61$ \\
\hline Intestine & $0.21 \pm 0.01$ & $0.19 \pm 0.08$ & $4.36 \pm 0.77$ & $2.50 \pm 0.65$ \\
\hline Heart & $0.38 \pm 0.03$ & $0.31 \pm 0.07$ & $1.98 \pm 0.11$ & $1.71 \pm 0.12$ \\
\hline Muscle & $0.22 \pm 0.13$ & $0.24 \pm 0.09$ & $0.61 \pm 0.05$ & $0.25 \pm 00.09$ \\
\hline Bone & $0.11 \pm 0.01$ & $0.15 \pm 0.03$ & $0.70 \pm 0.14$ & $0.30 \pm 0.21$ \\
\hline Spleen & $1.07 \pm 0.26$ & $0.88 \pm 0.11$ & $2.95 \pm 0.37$ & $2.28 \pm 0.71$ \\
\hline Tumor & $2.93 \pm 0.12$ & $1.61 \pm 0.22$ & $12.03 \pm 0.57$ & $1.37 \pm 0.22$ \\
\hline
\end{tabular}

\subsection{In vivo Nano $P E T / C T$ imaging}

The initial tumor-targeting efficacy and pharmacokinetic pattern of MUC1-[18 F]-SFB and MUC1-FA- $\left[{ }^{18} \mathrm{~F}\right] \mathrm{SFB}$ peptide conjugates were evaluated in SCID mice bearing subcutaneous MCF7 breast cancer cell line xenografts at $1 \mathrm{~h}$ with static scans. The uptake of tumor and major organs were quantified based on the analysis of NanoPET/CT images. The tumor uptake image of MUC1-[18 F]-SFB after $1 \mathrm{~h}$ p.i. was clearly visible with high contrast relative to background. This is clearly attributed to the washout of the radiotracer from adjacent organs and tissue (Fig. 3). In contrast, the tumor uptake of MUC1-FA- $\left[{ }^{18} \mathrm{~F}\right] \mathrm{SFB}$ after $1 \mathrm{~h}$ p.i. was clearly delineated with high contrast relative to background (Fig. 4). These images are in concurrent with finding obtained in quantitative biodistribution data reported in Table 3. The favorable biodistribution profile of MUC1-FA- $\left[{ }^{18} \mathrm{~F}\right] \mathrm{SFB}$ hybrid peptide conjugate warrant further evaluation and may tempt one to infer that this PET hybrid radiotracer may be useful as a dual receptor-targeting PET imaging molecular probe for breast cancer detection and monitoring tumor response to the treatment.

\section{Conclusion}

We have developed one-step and rapid synthetic approach for the radiofluorination of the receptor-targeting peptide and their hybrids via carbon atom nucleophilic displacement reactions. MUC1-[ $\left.{ }^{18} \mathrm{~F}\right] \mathrm{SFB}$ and MUC1-FA- $\left[{ }^{18} \mathrm{~F}\right] \mathrm{SFB}$ hybrid peptide conjugates were prepared with radiochemical yields greater than $70 \%$ in less than 30 min synthesis time. Radiochemical purities were found to be greater than 97\% without HPLC purification, which make this approach amenable for automation and suitable for large scale production. In vitro binding studies on MCF7 breast cancer cell line showed superior affinity of MUC1-FA-[ $\left.{ }^{18} \mathrm{~F}\right]$ SFB hybrid peptide over only MUC1-[18 $\left.\mathrm{F}\right] \mathrm{SFB}$ peptide conjugate. Biodistribution studies in normal mice revealed rapid blood clearance of these radioconjugates with excretion 
primarily by the urinary system for MUC1-[ $\left.{ }^{18} \mathrm{~F}\right] \mathrm{SFB}$ peptide and urinary as well as partially hepatobiliary systems for MUC1-FA- $\left[{ }^{18} \mathrm{~F}\right]$ SFB hybrid peptide conjugate. In SCID mice model bearing human breast cancer cell line xenografts, MUC1-FA-[ $\left.{ }^{18} \mathrm{~F}\right]$ SFB hybrid peptide demonstrated excellent tumor uptake and favorable pharmacokinetics over MUC1$\left[{ }^{18} \mathrm{~F}\right]$ SFB peptide conjugate. These observations were confirmed by initial Nano PET/CT imaging with high accumulation of radioactivity in tumor. These results demonstrate that MUC1-FA- $\left.{ }^{18} \mathrm{~F}\right] \mathrm{SFB}$ hybrid peptide conjugate may be useful as a dual receptor-targeting PET imaging probe for breast cancer detection and monitoring tumor response to the treatment, however, further evaluation is warranted.

\section{Declarations}

\section{Acknowledgments}

The authors wish to thank Mr. Mohamed Al-Amoudi for the Mass Spec. analysis. This project was supported by the King Abdulaziz City for Science and Technology (KACST) and the King Faisal Specialist Hospital \& Research Center (RAC \# 2100003).

\section{Availability of supporting data}

All data generated or analyzed during this study are included in this manuscript and its supplementary information files (mass spectrometric analysis and HPLC chromatograms) are also available upon request from the corresponding author.

\section{Funding}

This study was partially funded by the grants from King Abdulaziz City for Science and Technology (KACST grant).

\section{Author's contributions}

SMO and IJ conceived and designed the experiments. BAO and YAM performed all the experiments. AA performed cell studies. IJ and SMO drafted the manuscript. All authors contributed to the review and editing of the manuscript and approved the final manuscript

\section{Ethics approval}

Approval for the animal protocol used in this study was obtained from the Institutional Animal Care and Use Committee (King Faisal Specialist Hospital and Research Centre, Riyadh, KSA-ACUC; RAC \# 2100003). Animal studies were conducted strictly according to the international regulations governing the safe and proper use of laboratory animals

\section{Competing interests}

The authors declare they have no competing interests.

\section{References}

1. -Knutson KL, Schiffman K, Disis ML. Immunization with a HER-2/neu helper peptide vaccine generates HER2/neu CD8 Tcell immunity in cancer patients. J Clin Invest. 2001;107:477-84. 
2. -Brossart P, Wirths S, Stuhler G, Reichardt VL, Kanz L, Brugger W. Induction of cytotoxic T-lymphocyte responses in vivo after vaccinations with peptide-pulsed dendritic cells. Blood. 2000;96:3102-08.

3. -Kufe DW. Mucins in cancer: function, prognosis and therapy. Nat Rev Cancer. 2009;9:874-85.

4. -Lakshminarayanan V, Thompson P, Wolfert MA, Buskas T, Bradley JM, Pathangey LB, et al. Immune recognition of tumor-associated mucin MUC1 is achieved by a fully synthetic aberrantly glycosylated MUC1 tripartite vaccine. Proc Natl Acad Sci U S A. 2012;109:261-66.

5. -Singh R, Bandyopadhyay D. MUC1: A target molecule for cancer therapy. Cancer Biol Ther. 2007;6:481-66.

6. -Moore A, Medarova Z, Potthast A, Dai G. In vivo targeting of underglycosylated MUC-1 tumor antigen using a multimodal imaging probe. Cancer Res. 2004;64:1821-27.

7. -Muller S, Hanisch FG. Recombinant MUC1 probe authentically reflects cell-specific O-glycosylation profiles of endogenous breast cancer mucin. J Biol Chem. 2002;277:26103-12.

8. -Gendler SJ. MUC1, the renaissance molecule. J Mammary Gland Biol Neoplasia. 2001;6:339-53.

9. -Luo D, Qi W, Ma J, Wang YJ, Wishart D. Molecular mimicry of human tumor antigen by heavy chain CDR3 sequence of the anti-idiotypic antibody. J Biochem. 2000;128:345-7.

10. -Brossart P, Heinrich KS, Stuhler G, Behnke L, Reichardt VL, Stevanovic S, et al. Identification of HLA-A2Restricted T-Cell epitopes derived from the MUC1 tumor antigen for broadly applicable vaccine therapies. Blood. 1999;93:4309-17.

11. -Engelmann K, Baldus SE, Hanisch FG. Identification and topology of variant sequences within individual repeat domains of the human epithelial tumor mucin MUC1. J Biol Chem. 2001;276:27764-69.

12. - Pecher G, Finn OJ. Induction of cellular immunity in chimpanzees to human tumorassociated antigen mucin by vaccination with MUC-1 cDNA-transfected Epstein-Barr virus-immortalized autologous B cells. Proc Natl Acad Sci U S A. 1996;93:1699-704.

13. -Agrawal B, Reddish MA, Christian B, VanHeele A, Tang L, Koganty RR, et al. The antiMUC1 monoclonal antibody BCP8 can be used to isolate and identify putative major histocompatibility complex class 1 associated amino acid sequences. Cancer Res. 1998;58:5151-56.

14. -Hussain R, Courtenay-Luck NS, Siligardi G. Structure-function correlation and biostability of antibody CDRderived peptides as tumour imaging agents. Biomed Pept Proteins Nucleic Acids. 1996;97:67-70.

15. -Grinstead JS, Schuman JT, Campbell AP. Epitope mapping of antigenic MUC1 peptides to breast cancer antibody fragment B27.29: A heteronuclear NMR study. Biochemistry. 2003;42:14293-305.

16. -Krambovitis E, Hatzidakis G, Barlos K. Preparation of MUC-1 oligomers using an improved convergent solidphase peptide synthesis. J Biol Chem. 1998;273:10874-79.

17. -Girling A, Bartkova J, Burchell J, Gendler S, Gillett C, Taylor-Papadimitriou J. A core protein epitope of the polymorphic epithelial mucin detected by the monoclonal antibody SM-3 is selectively exposed in a range of primary carcinomas. Int J Cancer. 1989;43:1072-76.

18. -King P, Tjandra J, Reynolds K, McLaughlin P, Purcell D, Mc-Kenzie I. Reactivity of antihuman milk fat globule antibodies with synthetic peptides. J Immunol. 1989;142:3503-09.

19. -Xing PX, Reynolds K, Tjandra JJ, Tang XL, Purcell DFJ, McKenzie IFC. Synthetic peptides reactive with antihuman milk fat globule membrane monoclonal antibodies. Cancer Res. 1990;50:89-96.

20. -McAfee J, Neumann R. Radiolabelled peptides and other ligands for receptors overexpressed in tumor cells for imaging neoplasms. Nuc Med Biol. 1996;23:673-76. 
21. -Okarvi SM. Recent developments in ${ }^{99 \mathrm{~m}}$ Tc-labelled peptide-based radiopharmaceuticals: an overview. Nucl Med Commun. 1999;20:1093-112.

22. -Fishman A, Babich J, Strauss H. A ticket to ride: Peptide radiopharmaceuticals. J Nuc Med. 1993;34:2253-63.

23. -Boerman O, Oyen W, Corstens F. Radio-labeled receptor-binding peptides: A new class of radiopharmaceuticals. Semin Nucl Med. 2000;30:195-08.

24. -Okarvi SM, Jammaz I. Design, synthesis, radiolabeling and in vitro and in vivo characterization of tumor-antigenand antibody-derived peptides for the detection of breast cancer. Anticancer Res. 2009;29:1399-410.

25. -Okarvi SM, Jammaz I. Preparation and evaluation of the tumor-specific antigen-derived synthetic mucin 1 peptide: A potential candidate for the targeting of breast carcinoma. Nucl Med Biol. 2016;43:403-09.

26. -Campbell IG, Jones TA, Foulkes WD, Trowsdale J. Folate-binding protein is a marker for ovarian cancer. Cancer Res. 1991;51:5329-38.

27. -Antony AC. The biological chemistry of folate receptors. Blood. 1992;79:2807-20.

28. -Shannessy DJ, Somers EB, Maltzman J, Smale R, Fu YS. Folate receptor alpha (FRA) expression in breast cancer: identification of a new molecular subtype and association with triple negative disease. Springerplus. 2012;1:1-9.

29. -Ginter PS, McIntire PJ, Cui X, Irshaid L, Liu Y, Chen Z, Shin SJ. Folate Receptor Alpha Expression Is Associated With Increased Risk of Recurrence in Triple-negative Breast Cancer. Clin Breast Cancer. 2017;7:544-49.

30. -Varagnolo L, Stokkel MP, Mazzi U, Pauwels EK. ${ }^{18}$ F-Labeled radiopharmaceuticals for PET in oncology, excluding FDG. Nucl Med Biol. 2000;27:103-12.

31. -AlJammaz I, Al-Otaibi B, Abousekhrah A, Okarvi S. Rapid and one-step radiofluorination of bioactive peptides: Potential PET radiopharmaceuticals. J Appl Radiat Isot. 2014;91:17-23.

32. -AlJammaz I, Al-Otaibi B, Okarvi S, Amartey J. Novel synthesis of [ $\left.{ }^{18} \mathrm{~F}\right]$-fluorobenzene and pyridinecarbohydrazide-folates as potential PET radiopharmaceuticals. J Label Compd Radiopharm. 2006;49:125-37.

33. -Guide for. the Care of and Use of Laboratory Animals. Washington, DC: National Academy Press; 1996.

\section{Tables}

Table 1: Biodistribution of the MUC1-[18 F]SFB peptide conjugate in normal mice.

\begin{tabular}{|llllllllll|}
\hline min & Blood & Liver & Lung & Kidney & Intestine & Heart & Muscle & Bone & Spleen \\
\hline 10 & $9.77 \pm$ & $12.1 \pm$ & $4.52 \pm$ & 11.42 & $3.48 \pm$ & $4.77 \pm$ & $1.29 \pm$ & $1.34 \pm$ & $2.77 \pm$ \\
& 1.02 & 0.39 & 0.55 & \pm 2.41 & 1.01 & 0.69 & 0.09 & 0.16 & 0.25 \\
60 & $2.80 \pm$ & $2.88 \pm$ & $1.34 \pm$ & $3.43 \pm 0.45$ & $1.94 \pm$ & $1.77 \pm$ & $1.13 \pm 00.46$ & $1.31 \pm 0.28$ & $1.06 \pm$ \\
& 0.50 & 0.66 & 0.16 & & 0.23 & 0.24 & & 0.19 & $0.75 \pm 0.27$ \\
120 & $1.34 \pm$ & $1.59 \pm$ & $0.66 \pm$ & $1.09 \pm$ & $0.65 \pm 0.16$ & $0.44 \pm 0.23$ & $0.69 \pm 0.17$ & 0.09 \\
& 0.24 & 0.57 & 0.12 & 0.45 & & & & & \\
\hline
\end{tabular}

The values are average of $\%$ injected dose/gram \pm SD for $n=4$. 
Table 2: Biodistribution of the MUC1-FA-[18 F]SFB hybrid peptide conjugate in normal mice.

\begin{tabular}{|llllllllll|}
\hline min & Blood & Liver & Lung & Kidney & Intestine & Heart & Muscle & Bone & Spleen \\
\hline 10 & $3.63 \pm$ & $7.17 \pm$ & $7.84 \pm$ & 11.09 & $4.35 \pm$ & $3.57 \pm$ & $2.05 \pm$ & $0.20 \pm$ & $2.72 \pm$ \\
& 0.24 & 1.75 & 1.74 & \pm 1.41 & 0.91 & 0.19 & 0.45 & 0.09 & 0.65 \\
\hline 60 & $0.97 \pm$ & $2.61 \pm$ & $4.19 \pm$ & $5.36 \pm 0.10$ & $4.11 \pm$ & $1.17 \pm$ & $0.58 \pm 00.24$ & $0.02 \pm 0.01$ & $2.99 \pm$ \\
& 0.14 & 0.69 & 0.35 & & 0.34 & 0.24 & & & 0.89 \\
120 & $0.39 \pm$ & $1.00 \pm$ & $1.15 \pm$ & $2.39 \pm$ & $3.29 \pm 0.55$ & $0.41 \pm 0.12$ & $0.15 \pm 0.04$ & $0.01 \pm 0.0$ & $1.96 \pm 0.82$ \\
& 0.14 & 0.28 & 0.51 & 0.42 & & & & & \\
\hline
\end{tabular}

The values are average of $\%$ injected dose/gram \pm SD for $n=4$.

Table 3: Biodistribution of the MUC1- $\left[{ }^{18} \mathrm{~F}\right] \mathrm{SFB}$ and MUC1-FA-[18 $\left.\mathrm{F}\right] \mathrm{SFB}$ hybrid peptide conjugates in tumor-bearing SCID mice.

\begin{tabular}{|lllll|}
\hline \multicolumn{3}{|c|}{ MUC1 $-\left[{ }^{18} \mathrm{~F}\right] \mathrm{SFB}$} & \multicolumn{2}{c|}{ MUC1-FA $\left[{ }^{18} \mathrm{~F}\right] \mathrm{SFB}$} \\
\hline & $60 \mathrm{~min}$ & $60 \mathrm{~min}$ & $60 \mathrm{~min}$ & $60 \mathrm{~min}$ \\
& & blocked & & blocked \\
\hline Blood & $0.35 \pm 0.11$ & $0.39 \pm 0.15$ & $0.67 \pm 0.07$ & $0.52 \pm 0.05$ \\
\hline Liver & $0.85 \pm 0.07$ & $0.55 \pm 0.17$ & $3.20 \pm 0.36$ & $2.14 \pm 0.13$ \\
\hline Lung & $1.39 \pm 0.42$ & $0.99 \pm 0.22$ & $2.96 \pm 0.40$ & $2.05 \pm 0.49$ \\
\hline Kidney & $1.28 \pm 0.03$ & $1.20 \pm 0.23$ & $5.14 \pm 0.53$ & $1.86 \pm 0.61$ \\
\hline Intestine & $0.21 \pm 0.01$ & $0.19 \pm 0.08$ & $4.36 \pm 0.77$ & $2.50 \pm 0.65$ \\
\hline Heart & $0.38 \pm 0.03$ & $0.31 \pm 0.07$ & $1.98 \pm 0.11$ & $1.71 \pm 0.12$ \\
\hline Muscle & $0.22 \pm 0.13$ & $0.24 \pm 0.09$ & $0.61 \pm 0.05$ & $0.25 \pm 00.09$ \\
\hline Bone & $0.11 \pm 0.01$ & $0.15 \pm 0.03$ & $0.70 \pm 0.14$ & $0.30 \pm 0.21$ \\
\hline Spleen & $1.07 \pm 0.26$ & $0.88 \pm 0.11$ & $2.95 \pm 0.37$ & $2.28 \pm 0.71$ \\
\hline Tumor & $2.93 \pm 0.12$ & $1.61 \pm 0.22$ & $12.03 \pm 0.57$ & $1.37 \pm 0.22$ \\
\hline
\end{tabular}

The values are average of $\%$ injected dose/gram $\pm S D$ for $n=4$.

\section{Figures}




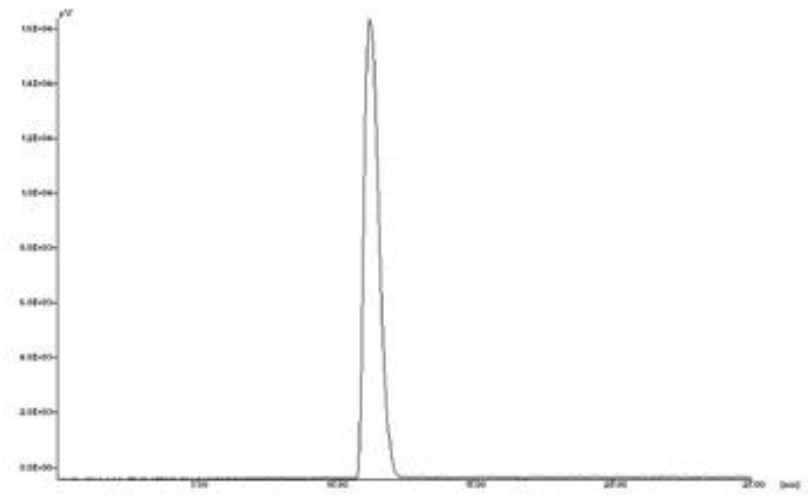

(A)

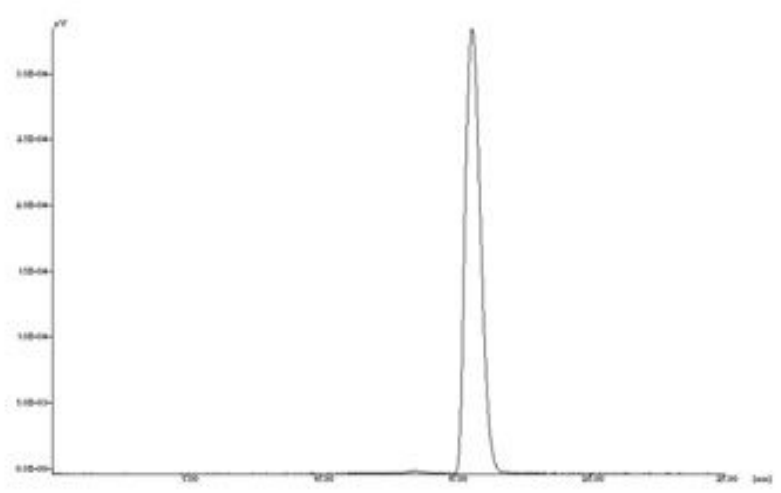

(B)

Figure 1

HPLC chromatograms of MUC1-[18F]SFB peptide (A) and MUC1-FA-[18F]SFB hybrid peptide conjugates (B).

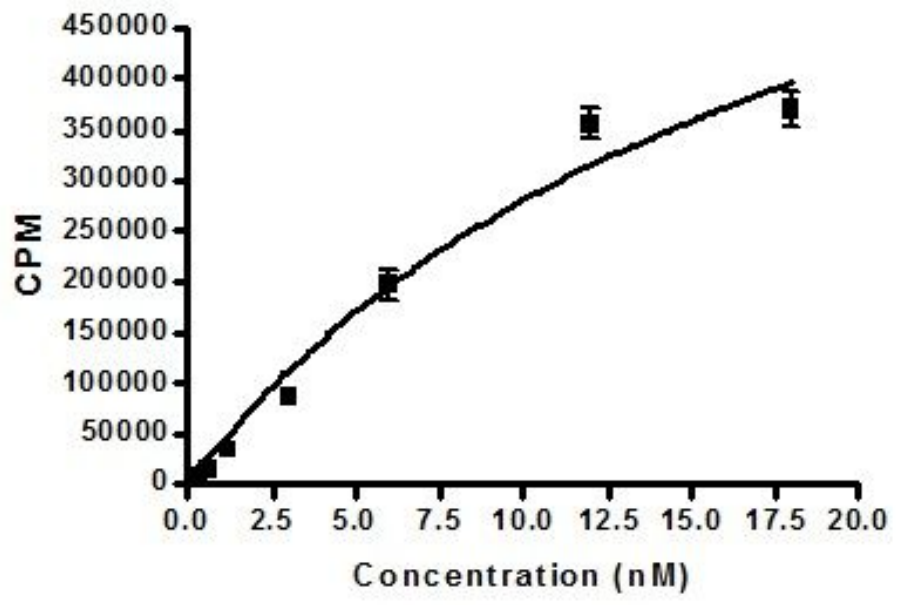

(A)

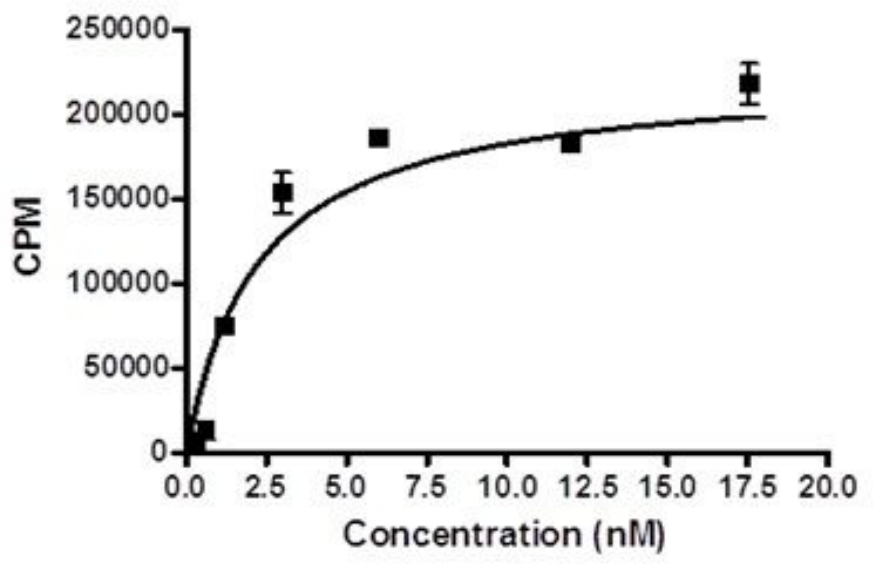

(B)

\section{Figure 2}

Determination of binding affinity (Kd) values of MUC1-[18F]SFB (A) and MUC1-FA-[18F]SFB hybrid peptide conjugates in MCF7 breast cancer cell line. 

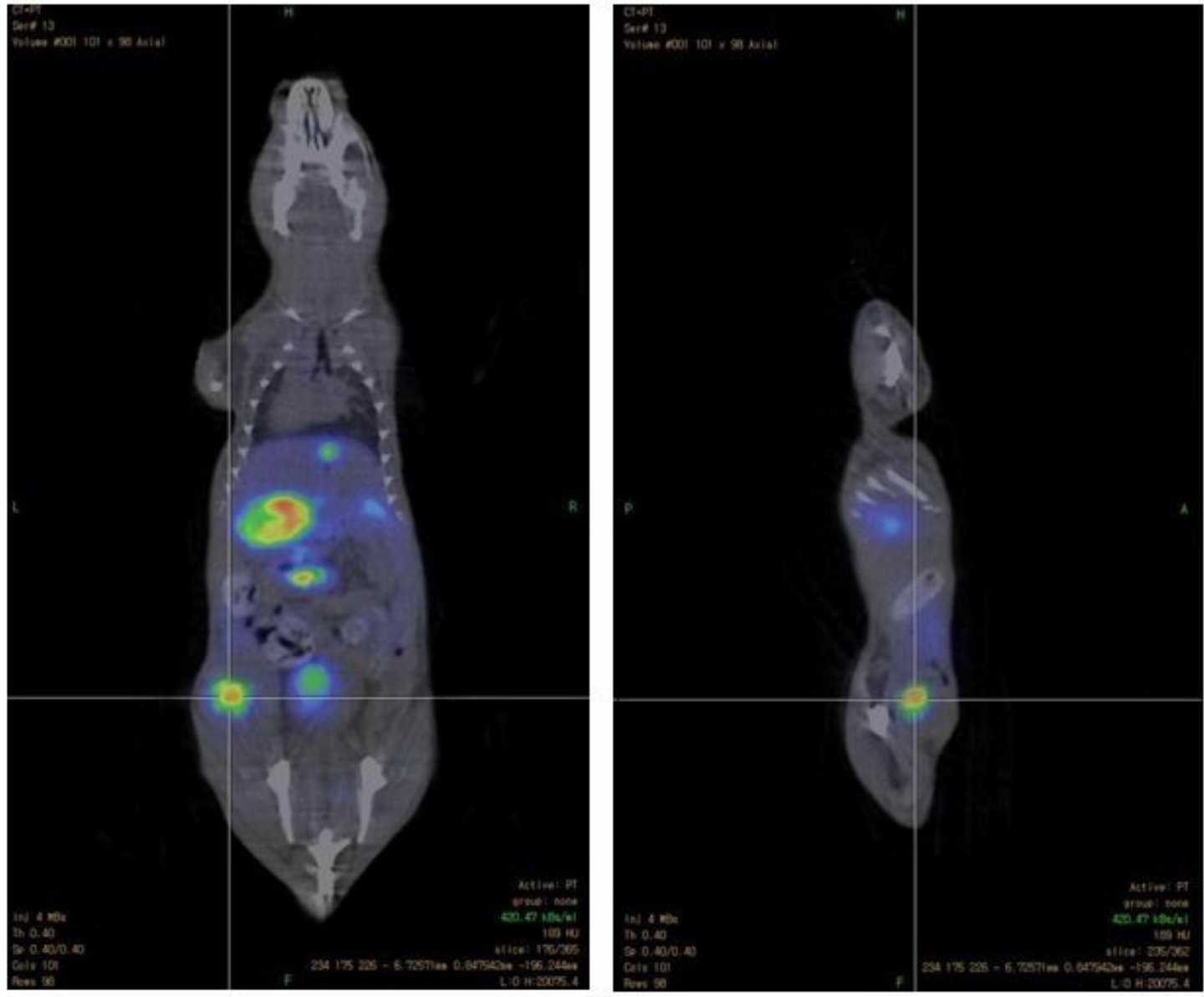

\section{Figure 3}

Coronal and sagittal images of tumor-bearing mouse after $1 \mathrm{~h}$ post injection using $5 \mathrm{MBq}$ MUC1-[18F]SFB peptide conjugate. 

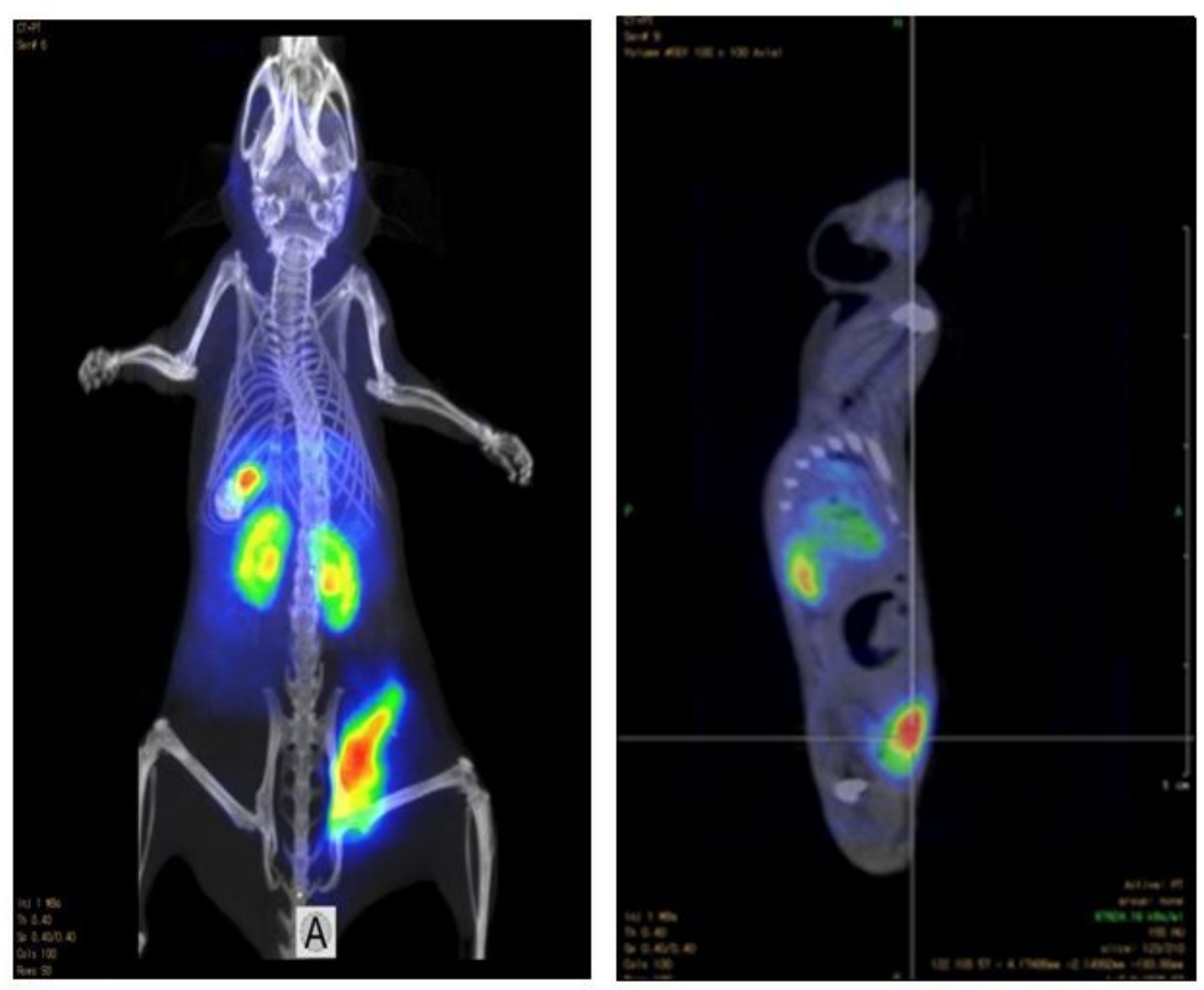

Figure 4

Coronal and sagittal images of tumor-bearing mouse after $1 \mathrm{~h}$ post injection using 5 MBq MUC1-FA-[18F]SFB hybrid peptide conjugate. 


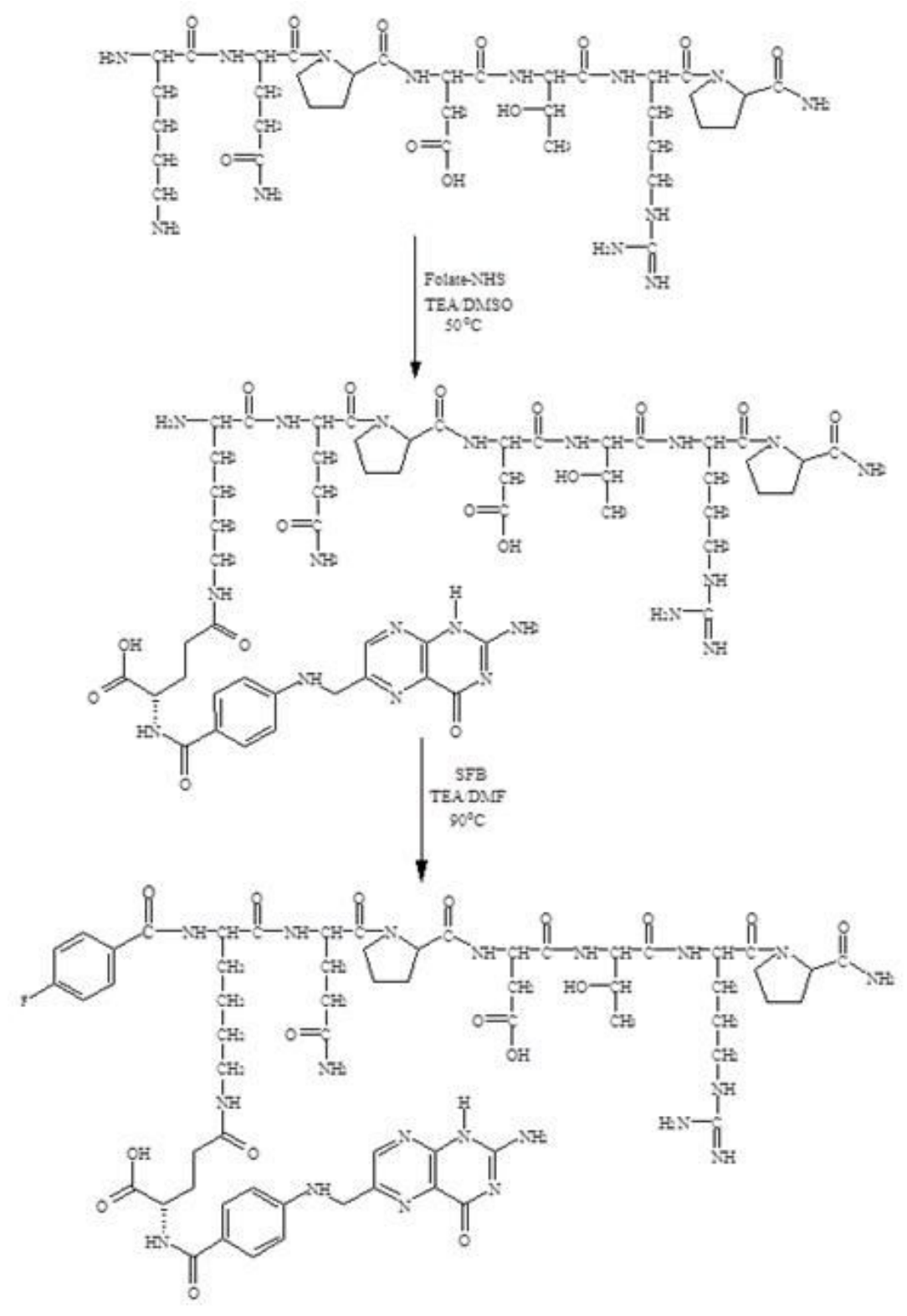

Figure 5

Synthesis of the MUC1-FA hybrid peptide and reference MUC1-FA-SFB hybrid peptide conjugate. 
<smiles>Cc1ccc(C(=O)O)cc1</smiles>

$\stackrel{\text { TSTU/TEA }}{\longrightarrow}$<smiles>CNC</smiles><smiles>O=C1CCC(=O)N1</smiles><smiles>COC(=O)c1ccc(N(C)C)cc1</smiles><smiles>C[N+](C)(C)c1ccc(C(=O)ON2C(=O)CCC2=O)cc1</smiles>

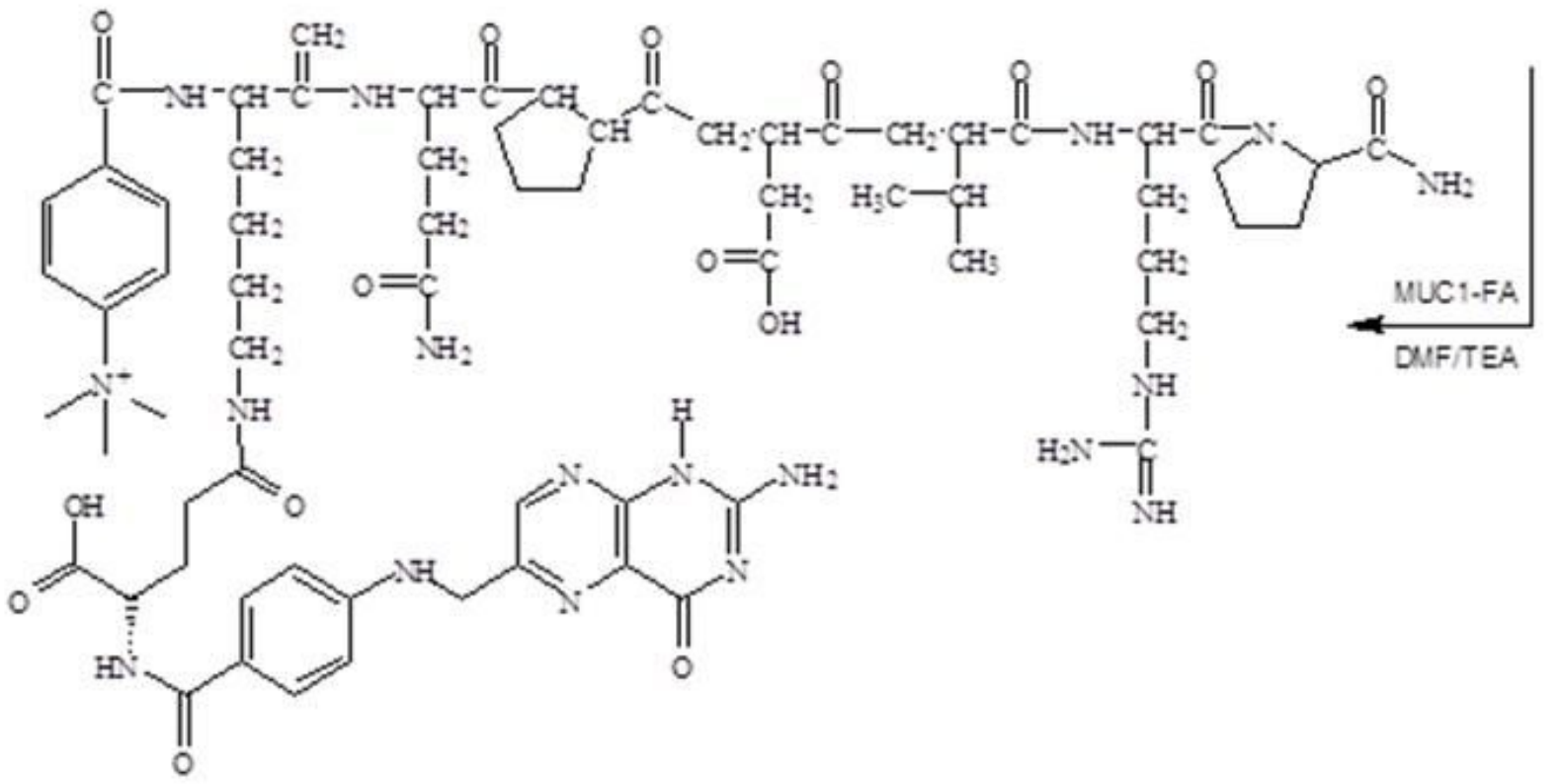

Figure 6

Synthesis of the MUC1-FA-4-benzoate hybrid peptide triflate precursor. 
<smiles>C=C(NC(=O)c1ccc([N+](C)(C)C)cc1)NC(CCC(N)=O)C(=O)C1CCCC1C(=O)CC(CC(=O)O)C(=O)CC(C(=O)NC(CCCN)CCCN)C(C)C</smiles><smiles>C=C(NC(=O)c1ccc(F)cc1)NC(CCC(N)=O)C(=O)C1CCCC1C(=O)CC(CC(=O)O)C(=O)CC(C(=O)NC(CCCCN)C(=O)N1CCCC1C(N)=O)C(C)C</smiles>

Figure 7

Radiosynthetic approach for MUC1-[18F]SFB peptide conjugate. 

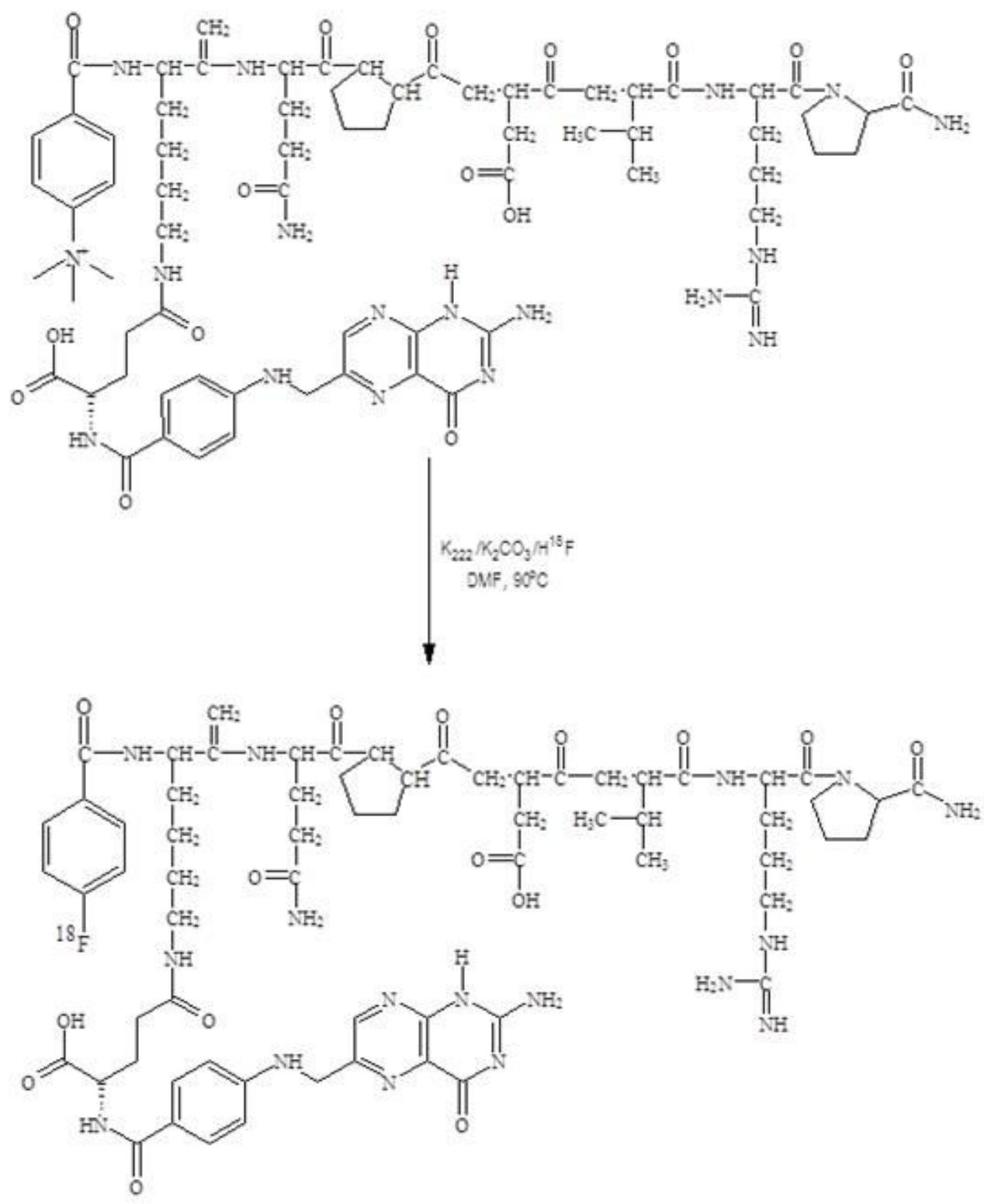

\section{Figure 8}

Radiosynthetic approach for MUC1-FA-[18F]SFB hybrid peptide conjugate. 